Meta

Journal des traducteurs

Translators' Journal

\title{
News Translation and Translation Ethics in the Cypriot Context
}

\section{Georgios Floros}

Volume 57, numéro 4, décembre 2012

Journalisme et traduction

Journalism and Translation

URI : https://id.erudit.org/iderudit/1021225ar

DOI : https://doi.org/10.7202/1021225ar

Aller au sommaire du numéro

\section{Éditeur(s)}

Les Presses de l’Université de Montréal

\section{ISSN}

0026-0452 (imprimé)

1492-1421 (numérique)

Découvrir la revue

\section{Citer cet article}

Floros, G. (2012). News Translation and Translation Ethics in the Cypriot Context. Meta, 57(4), 924-942. https://doi.org/10.7202/1021225ar

\section{Résumé de l'article}

D'importantes questions relatives à la traduction des nouvelles journalistiques sont encore débattues. Parmi elles, certaines concernent le concept de contrôle d'accès, le recours à des modèles traditionnels et la question même de la définition de la traduction. La présente communication entend donc mettre l'accent sur l'utilisation de la traduction dans la production d'informations au sein du contexte chypriote : des données provenant de journaux chypriotes et de l'Office chypriote de la presse et de l'information suggèrent que la traduction serait utilisée dans la diffusion de la politique nationale d'une manière incompatible avec les pratiques relatives à l'éthique de la traduction. Or si la presse est presque toujours, par nécessité, un véhicule de l'idéologie nationale, il n'en est pas nécessairement de même pour les traductions. L'objectif final est de montrer comment les idéologies nationales violent l'informativité souhaitée des nouvelles et de remettre en question l'« uniformité » éthique constatée entre information originale et information traduite, en faveur d'une plus haute conscience éthique de la part des journalistes et des journaux. L'article est sous-tendu par l'idée que la traduction des nouvelles pourrait être envisagée selon les mêmes considérations éthiques que la traduction dans le sens classique du terme, en dépit de la recontextualisation et du filtrage des contenus.
Ce document est protégé par la loi sur le droit d'auteur. L'utilisation des services d'Érudit (y compris la reproduction) est assujettie à sa politique d'utilisation que vous pouvez consulter en ligne.

https://apropos.erudit.org/fr/usagers/politique-dutilisation/ 


\title{
News Translation and Translation Ethics in the Cypriot Context
}

\author{
GEORGIOS FLOROS \\ University of Cyprus, Nicosia, Cyprus \\ gfloros@ucy.ac.cy
}

\begin{abstract}
RÉSUMÉ
D'importantes questions relatives à la traduction des nouvelles journalistiques sont encore débattues. Parmi elles, certaines concernent le concept de contrôle d'accès, le recours à des modèles traditionnels et la question même de la définition de la traduction. La présente communication entend donc mettre l'accent sur l'utilisation de la traduction dans la production d'informations au sein du contexte chypriote: des données provenant de journaux chypriotes et de l'Office chypriote de la presse et de l'information suggèrent que la traduction serait utilisée dans la diffusion de la politique nationale d'une manière incompatible avec les pratiques relatives à l'éthique de la traduction. Or si la presse est presque toujours, par nécessité, un véhicule de l'idéologie nationale, il n'en est pas nécessairement de même pour les traductions. L'objectif final est de montrer comment les idéologies nationales violent l'informativité souhaitée des nouvelles et de remettre en question l'«uniformité » éthique constatée entre information originale et information traduite, en faveur d'une plus haute conscience éthique de la part des journalistes et des journaux. L'article est sous-tendu par l'idée que la traduction des nouvelles pourrait être envisagée selon les mêmes considérations éthiques que la traduction dans le sens classique du terme, en dépit de la recontextualisation et du filtrage des contenus.
\end{abstract}

\begin{abstract}
In news translation, some of the most prominent issues still debated on concern news translation as gatekeeping, the application of traditional models and the issue of the very definition of translation itself. Within this context, this paper will focus on the use of translation in news production in the Cypriot context. Data from Cypriot newspapers and the Cypriot Press and Information Office (PIO) point to the assumption that translation is used for disseminating national policy in ways which might stand in a conflicting relationship with issues pertaining to translation ethics. While news reporting is almost by necessity a carrier of national ideology, the same cannot be assumed automatically for material which is translated. The ultimate aim is to show how national ideologies violate the desired informativity of news and to challenge the ethical "uniformity" observed between news reporting and news translation, in favor of a higher ethical awareness on the part of journalists and newspapers. The underlying premise of the article is that news translation could perhaps be treated according to the same ethical considerations as translation in the conventional sense, despite the recontextualization and filtering of the content expressed.
\end{abstract}

\section{MOTS-CLÉS/KEYWORDS}

nouvelles (actualités), discours rapporté, éthique de traduction, relativité de l'éthique, Chypres

news, reported speech, translation ethics, ethical relativity, Cyprus 
Ever since the rapid growth of the information dissemination industry as a result of globalization, news translation has started gaining increased attention as a specific kind of translation within Translation Studies. Some of the most prominent issues still discussed concern gatekeeping, i.e., the various selection procedures which news items or parts thereof undergo when translated for different audiences, or transediting, i.e., the description of news translation as a liminal space between translation proper and editing (see Fujii 1988; Bell 1991; Vuorinen 1995; Hursti 2001; Gambier 2006; Stetting 1989; Bielsa 2007), the application of traditional analytical models and criteria on news translation (see Bielsa and Bassnett 2009, especially Chapters 4 and 5) and the challenging of the very definition of translation (initiated in Bassnett 2006 and explicitly discussed in Bielsa and Bassnett 2009). In the framework of this debate, this paper will focus on the use of translation in news production in the Cypriot context with examples from newspapers and English-language press reviews of the Press and Information Office of the Republic of Cyprus ${ }^{1}$. The data point to the assumption that translation is used for disseminating and consolidating national policy in ways which might stand in a conflicting relationship with issues pertaining to translation ethics. While original news reporting is almost by necessity a carrier of national ideology, the same cannot be assumed automatically for material which is translated. The ultimate aim of the paper is to show how national ideologies, which codify subjective interpretations of historical events, violate the desired informativity of the news, and to challenge the ethical uniformity noted in these types of discourse in favor of a higher ethical awareness on the part of journalists and newspapers. The underlying premise of the paper is that news translation should preferably be treated on the basis of the same ethical considerations as translation in the conventional sense, despite the recontextualization, filtering and transformation of the content expressed (gatekeeping and/or transediting).

To this end, this article will first engage in a more general discussion of the practices constituting what we call news translation today, as well as in a discussion of the repercussions of those practices at the theoretical level, specifically with regard to the fundamental question of the definition of translation; the aim is to lay down important parameters for the discussion of the examples, which will be presented in the second part along with an historical account as well as a linguistic analysis of how the aforementioned violation of informativity is realized. In the third part of the article, the examples will be further discussed with the specific aim to challenge current practices in the Cypriot context from the point of view of translation ethics.

\section{News translation: Legitimizing a reconceptualization of Translation?}

To begin with, it would be useful to make a terminological clarification regarding news translation. Most of the bibliography on this quite special, yet not fully explored, domain within both Translation Studies and Journalism is preoccupied either with global examples of international agencies disseminating news around the world (see above), or with the tailoring of international news for local audiences: in the past decade, there has emerged a number of works which provide illuminating insights by examining the translation and recontextualization of news for local contexts such as the Canadian (Conway 2006), the Chinese (Sorby 2006), the Italian (Orengo 2005), 
the Korean (Kang 2007), the Norwegian (Erdal 2009), the Spanish (Valdeón 2005) and the Taiwanese (Tsai 2005) ones. In a nutshell, the overall consensus seems to be that news translation actually implies a significant transformation of news items as they cross linguistic and cultural boundaries. For this reason, the terms gatekeeping (White 1950) and transediting (Stetting 1989) have been used as alternatives to news translation in order to account for two significant aspects: on the one hand for stressing the various selection stages, on the other hand for describing news translation as a combination of translation and editing. In both cases, however, translation is viewed as merely one of the processes involved in news circulation.

Bielsa and Bassnett however opt for the term news translation rather than transediting in order to refer to the

particular combination between editing and translating, and more specifically to the form that translation takes when it has become integrated in news production," mainly because transediting erroneously implies "the existence of another form of translating news. (Bielsa and Bassnett 2009: 64)

Further, they argue that "the journalist who writes a text does not possess a significantly different status from the journalist who translates it" (Bielsa and Bassnett 2009: 65). This paper will follow Bielsa and Bassnett in their terminological choice, not so much because of an assumed uniformity of the status of journalists, but because the basic distinction in journalistic work cannot only be that between original and translated news production. Besides translated news production, news translation may also encompass hybrid forms of original and translated news items, for example in the case of foreign-language quotes embedded in original production. Thus the term news translation should be upheld as an overarching term for all possible hybrid subforms that translation may take on within the news industry.

The significant transformation of news items as they cross boundaries and (audience) expectations is an issue which has sufficiently been described both in terms of style and in terms of additions, omissions and permutations. There is also an extensive discussion on the ideological implications of the transforming practices applied in order to tailor a news item for a different audience. As was to be expected, questions concerning the reconceptualization of translation in its traditional sense and the issue of the very definition of translation soon became relevant. The discussion has thus touched upon the very core of Translation Studies as a discipline: in her introduction to the proceedings of a conference held at the University of Warwick, Susan Bassnett explicitly poses the question of redefining translation to account for the conditions set by news translation, as these are highlighted in various papers on news translation:

[A]nother important research question [has] started to emerge involving the very definition of translation itself. Since news translation is not strictly a matter of interlingual transfer of text $\mathrm{A}$ into text $\mathrm{B}$ but also necessitates the radical rewriting and synthesizing of text A to accommodate a completely different set of audience expectations, criteria applicable to the analysis of the translation of print documents, whether technical or literary, no longer serve the same purpose. (Bassnett 2006: 6)

Furthermore, Bielsa and Bassnett argue that the traditional understanding of translation is challenged in the context of the global media world: 
Information that passes between cultures through news agencies is not only "translated" in the interlingual sense, it is reshaped, edited, synthesized and transformed for the consumption of a new set of readers. It would seem that in the global media world, the very definition of translation is challenged and the boundaries of what we might term translation have been recast. (Bielsa and Bassnett 2009: 2)

In the comprehensive account they provide of the ways in which the traditional understanding of translation can be challenged in the light of the new conditions set by news translation, the authors deploy a number of analytical models and criteria. Their discussion of the theoretical apparatus of Translation Studies in relation to the particularities of news translation seems to imply that this apparatus may not be sufficient for analyzing news translation, and that, therefore, new directions need to be examined such as those opened by localization and research on interpreting. For example, the authors suggest that skopos theory has its limitations with regard to news translation, because "[t]he enormous divergence of presentational aspects takes us beyond the interlingual into other aspects of textual manipulation that prevail in the target culture" (Bielsa and Bassnett 2009: 118). They also suggest that the adoption of a theory of localization might be more helpful (see also Orengo 2005). In this framework, the only concept of equivalence that might be upheld for news translation, as well as for most forms of translation, is, according to the authors, that of equivalence of effect (see Bielsa and Bassnett 2009: 8). The call for recourse to research on interpreting is mainly due to the need for instantaneous circulation of news in a domesticating way, which presents a parallel to the work of interpreters (see Bielsa and Bassnett 2009: 16). A more fundamental concern emerges in the authors' challenging of the existence of a source text as well as of authorship in the sense these are understood in literary translation. In a nutshell, Bielsa and Bassnett rightfully question the existence of a source text on the grounds that the extreme reshaping and repurposing of whatever could be considered a source text for news production and the absence of one author make it quite difficult to detect a linear process of transfer or to talk about faithfulness to an author or to an original (see Bielsa and Bassnett 2009: 66). Finally, throughout their work, Bielsa and Bassnett assert that the textual transformation taking place when news is translated aims at satisfying target reader expectations.

Returning to what seems to be a very important question for Translation Studies as a discipline - that of recasting the boundaries of translation and reconceptualizing its very definition - one may confidently admit that a number of pragmatic reasons indeed justify the view that news translation is yet another form of translation next to other, more traditional ones. But, epistemologically speaking, the striking differences emerge because of the extreme degree in which characteristics, otherwise inherent in any translation, are present, rather than through particular characteristics per se. For example, the need for instantaneous transmission and dissemination of news through translation is not that much different from the requirement for instantaneity in preparing technical translations or other forms of what has been termed pragmatic translation.

The nature and existence of a source text and the issue of authorship have already been challenged in the framework of literary translation, which is by definition the gate through which contemporary literary theory and criticism keep entering Translation Studies. Despite the traditional (physical) form in which the literary 
source text may appear, the theory of intertextuality, as discussed by Barthes (1981) and Kristeva (1984), prompts us to abandon traditional perceptions of the notion of text and shift to the notion of intertext, which points to the possibility of perceiving a text rather as a conglomeration of texts (and narratives). ${ }^{2}$ This floating nature of the source text is thus by no means a particularity of news translation. But it is certainly true that in news translation this floating nature becomes particularly apparent. Besides the floating nature of the source text, an example which may lead to a reconsideration of there being $a$ source text is presented by law texts produced by the EU, where multiple linguistic versions are attributed equal value as originals, since, for example, the translation into all official languages may be done on the basis of either the English or the French version.

Both the existence of a source text and the issue of authorship are closely connected to the questions of the absence of an author or of the existence of multiple authors. News translation is not substantially different from other forms of translation in this respect. The translation of many different genres (e.g., advertisements, financial reports and literary texts) has already challenged the concept of being faithful to an author. In fact, it has been possible to discuss such forms of translation in terms of equivalence, function, norms and target readers despite the inability to pinpoint a particular author. The central, almost sacral, importance attributed to authorship in many forms of translation has strongly been challenged by postcolonial and feminist approaches (see, for example, Simon 1996; Simon and St-Pierre 2000). But it is again true that in some cases of news translation, an author cannot even be assumed, as might be done for other textual manifestations.

Perhaps the most striking difference when comparing news translation to more conventional forms of translation is the occurrence of radical permutations in news translation. Editing reaches extreme levels in news translation, to the extent that the news read by target audiences do not always stand in a recognizable relationship with the original news. Such practices, which are very common in news translation, combined with the rather simplistic understanding of translation as mere interlingual transfer or as literal translation on the part of journalists (see Bielsa and Bassnett 2009: 1), prompt a viewing of translation as just another editing technique within news production. But translation is not simply a tool for editing; it may itself include severe editing and repurposing, as argued among others by Tymoczko and Gentzler (2002: xxi, quoted in Bielsa and Bassnett 2009: 7), and as becomes particularly evident in the translation of commercial material and interviews, in localization and other skopos-determined instances such as summarizing through translation - the extensive functionalist approach by Nord 2005 is of particular importance in this regard. Therefore, it can again be argued that extreme editing cannot be thought of as a particularity of news translation, as a number of examples show that editing can take place in all forms of translation and in many ways, not excluding the addition of background knowledge, nuancing and change of angle. Confining translation to the literal mode is, rather, a matter of misconception of the possibilities of translational work on the part of journalists. Presumably, the main reason behind this downgrading could be the journalists' confidence that they know the demands and expectations of the target audience. But, as Bielsa and Bassnett quote from a translator-editor who was interviewed during fieldwork conducted in 2004: 
In news, I don't know to which extent [translation] is so invisible, because we are directly transforming a reality that comes from a different context for a public whose characteristics we believe we know. I think that in many cases the journalistic sense of the translator prevails. (Bielsa and Bassnett 2009: 93; my emphasis)

In news (translation), as perhaps in many other occasions, only assumptions can be made as to reader expectations, which are by necessity conditioned by time and situation, even within the same local context. If audiences do not react to or revolt against the way news is presented, this is not always to be taken as tantamount to a silent confirmation of the journalists' assumptions. Therefore, the tailoring of news according to reader expectations seems to be a fallacy. This does not imply that translators have better knowledge of reader expectations in advance, either. However, the crucial differences when it comes to translation are that translators may often be briefed by or negotiate with commissioners regarding the translational output, and that the assumptions made by translators regarding reader expectations are of a more general nature, and thus perhaps safer. For example, translators can base their choices on the safe assumptions that a product needs to be sold (e.g., localization), or that they must prevent damage from incurring to the users of a text (e.g., translation of manuals). Thus, the extreme textual transformation in news translation is not a matter of satisfying readers, but a result of the norms which are prevalent in each context, whatever the way in which they are formed and sustained.

The above analysis does not aim at oversimplifying things or at treating as redundant the systematic examination of the processes and characteristics of a newly acknowledged form of translation. It aims to stress that translation, both as discipline and practice, is broad enough to accommodate news translation as a separate form of translation without the need to renegotiate essentially its definition - if there is one which is agreed on. It also aims to stress that the particularity of news translation is constituted primarily through the norms governing it. As with any contemplation of norms, we therefore need to engage in a discussion of power relations and of the ethical. In other words, the generic difference of news translation concerns the particularities of its ethics. And it is precisely the investigation of the above-mentioned (extreme) characteristics which opens up the way for an ethical contemplation of news translation. But what could be so special - or particular - about the ethics of news translation?

News translation is one of many other forms of translation which are integrated ${ }^{3}$ in another profession, as are, for example, the translation of advertisements and localization, which are integrated in marketing, some forms of literary translation, which are occasionally integrated in the publishing industry, or legal translation, which is integrated in law professions. Most professions which integrate translation impose their norms on the translational product, but at the same time leave enough space for translational norms to operate. But unlike in most professions, the norms in news translation are fully dictated by journalists and the news industry. So, while other professions may establish a more or less felicitous synergy with translation, the news industry imposes itself wholly on translation. The responsibility about what is right or wrong and about the possible consequences of a news item are fully assumed by journalists and not by the persons who should be responsible (and hopefully trained on how to be responsible) for a textual transformation based on translation. As a consequence, Translation Studies as a discipline needs to position itself on the 
conditions under which translation is used in the framework of news production, as markets always go their own way. However, instead of constantly redefining the very object of study, we may investigate particularities and account for them, but also provide the theoretical framework for contemplating consequences, awareness and responsibility vis-à-vis those aspects of the synergy which touch upon translation. In addition, Translation Studies may play a very important role simply by posing and contemplating on the question of how far the transformation of a text through translation may go. By posing this question, this paper attempts to pick up on some very important issues already introduced by Gambier (2006) in his paper on transformations in international news, where a discussion of the translators' position and the extent to which they can intervene is initiated.

Before discussing ethical aspects of news translation, however, a set of examples from the Cypriot context will be presented in the next section. It is hoped that these examples will contribute not only to understanding the Cypriot context, but also to drawing conclusions of a possibly wider validity for the area discussed.

\section{The Cypriot context: Narratives and practices}

This section will begin with an historical account of events, so as to provide the necessary context for explaining the emergence of very strict practices in the Cypriot media. This context will help understand the particular narrative ${ }^{4}$ reproduced in the examples to follow. It needs to be admitted in advance that, despite all efforts, the account given here cannot be objective in the strictest sense of the term, as the author of this paper is a member of a cultural formation clearly in favor of one of the sides involved.

\subsection{Historical account and fields of tension}

The Republic of Cyprus was declared an independent state in 1960, following a fiveyear independence struggle against British colonial rule. The newly-founded state consisted of two communities, a Greek Cypriot and a Turkish Cypriot one, the former representing around $82 \%$ of the population, and the latter representing the remaining $18 \%$. The new constitution stipulated, among other things, that the official languages of the new state would be both Greek and Turkish. Due to the ethnic constellation and the former regime, Britain, Greece and Turkey would be the guarantor powers of the new state. Soon after the declaration of independence, conflicts broke out between the two communities, which escalated to armed clashes and even led to a de facto division of the capital, Nicosia, as early as 1963. The situation deteriorated over the years. Meanwhile, in 1967, the military coup in Greece established a dictatorship which lasted until 1974. It was in that year that the Greek military junta perpetrated a coup against Cyprus' elected government as well. Turkey, exercising its guarantor rights, referred to Article 4 of the Treaty of Guarantee and invaded Cyprus with the aim of protecting the Turkish Cypriot population against the attempted coup. Despite the failure of the coup in Cyprus and the restoration of democracy in Greece, Cyprus still remains a divided and traumatized country with both communities having to suffer a lot over the years: a violent exchange of populations, numerous missing persons and a still unresolved political issue with a deep and painful impact on the social and cultural structuring of both sides. 
According to the Cyprus Ministry of Foreign Affairs, the Turkish Cypriot leadership declared the areas occupied by the Turkish army, by then inhabited almost exclusively by Turkish Cypriots, an independent state by the name of "Turkish Republic of Northern Cyprus" (TRNC) in 1983. ${ }^{5}$ The United Nations never recognized this state and the Republic of Cyprus considers the state as illegal and its areas as occupied territory of the Republic of Cyprus. Numerous efforts have been made towards a solution ever since and, recently, after the rejection of the Anan plan in 2004 by the clear majority of the Greek Cypriots, a new round of talks between the two communities started and negotiations are currently ongoing. The TRNC sees itself as the expression of a minority struggling for status, while the Republic of Cyprus sees this formation as an open wound and a continuous threat.

\subsection{Current practices in the Cypriot media}

The above is more or less the narrative upheld by the Greek Cypriot side. This narrative led to the formation of a very strict media policy on the Greek Cypriot side. In their effort to support the claim that the Turkish invasion was in violation of all rules of international legality and to point out that the ensuing formation of the TRNC was condemned by the UN, all Greek Cypriot governments stress the illegality of the TRNC by referring to it as the pseudo-state. In news reporting, all institutions of the TRNC are referred to using modifiers such as illegal or so-called, or quotation marks. Thus, for example, the government of the TRNC is the illegal government, the Ercan Airport of Lefkoşa (the northern part of the divided capital Nicosia) is the illegal airport of Tymbou (after the Greek name of the area), and the country's High Court is the so-called High Court. This policy is followed by all Greek Cypriot media with very rare exceptions. In fact, failing to describe the state or its institutions with the above modifiers equals their silent and de facto recognition, which has to be avoided at all costs. The use of the above modifiers varies across different media and modes of discourse. In oral discourse, for example, the modifier illegal is preferred, while in written discourse, as in newspapers, all possible kinds of the above modifiers (adjectives or quotation marks) can be found. In subtitling, quotation marks are favored, probably due to limited space and necessary condensation techniques. Within the framework of this policy, all official contacts, collaborations and the acceptance of official invitations between political and educational institutions of the Republic of Cyprus and institutions of the occupied areas are prohibited by the Republic of Cyprus, as they would imply the official recognition of the respective Turkish Cypriot institutions and, by consequence, of the TRNC. When translating any reference to the TRNC and its institutions, a very specific norm, namely denial of status, is highly respected.

It is very hard to distinguish to what extent the above policy constitutes intervention in the strict sense of the term, since it is impossible to tell whether there is imposition of ideology on the various media by the government. The acceptance this policy enjoys by Greek Cypriot media ${ }^{6}$ points to the possibility of complete acceptance of the government policy by media. Such a possibility notwithstanding, this is a clear instance of political ideology flowing into media. So, irrespectively of whether it is an extreme or a mild case of political ideology affecting media discourse, the use of the term intervention is still justified. The important aspect here is the effect this 
intervention aims to achieve. The aim is for the Turkish Cypriot institutions to be deprived of their legal status as institutions, so as ultimately to denounce the legal status of the whole state. As a result, this practice does not only comply with the official foreign policy of the Republic of Cyprus, but, most probably, also pursuits the satisfaction of public feeling.

\subsection{Examples}

The examples presented below have been selected to represent two different uses of news translation:

a) newspaper reports constructed almost exclusively through translation of various sources, the source language for the quoted material being Turkish (group A);

b) press releases providing a review in English of various Turkish Cypriot and Turkish press sources in order for this review to serve as a source for various other international news organizations and local ${ }^{7}$ or foreign media (group B).

The three examples representing group A have been selected from the two major newspapers circulating in the Republic of Cyprus, Politis ${ }^{8}$ [citizen] (Example 1) and Fileleftheros ${ }^{9}$ [liberal] (Examples 2 and 3), both designating themselves as politically neutral. Another two examples (4 and 5) represent group B; these are press reviews by the Press and Information Office of the Republic of Cyprus (PIO). The choice for both groups covers the period from 2008 to 2011 and was made randomly, so as to be as representative as possible of the current practices in Cyprus. Some instances in all examples have been underlined so as to facilitate the ensuing discussion. For group A examples, my literal translations/glosses are provided.

\subsubsection{Group A}

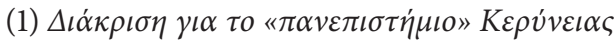

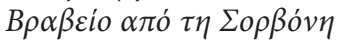

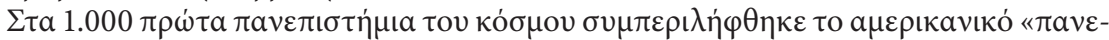

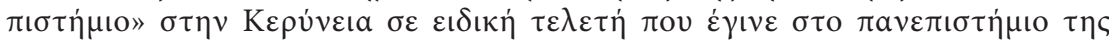

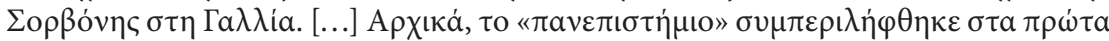

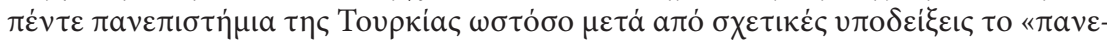

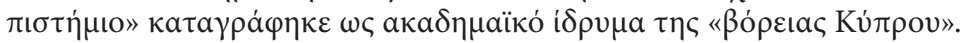

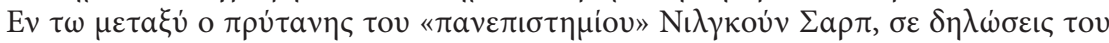

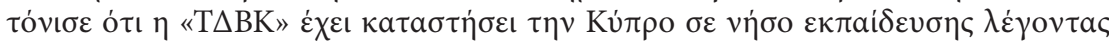

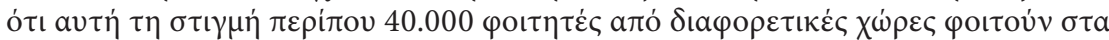

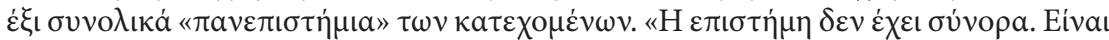

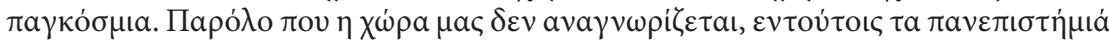

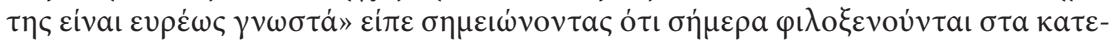

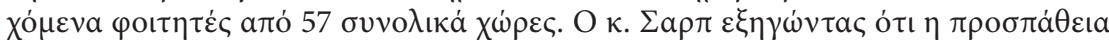

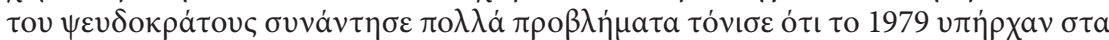

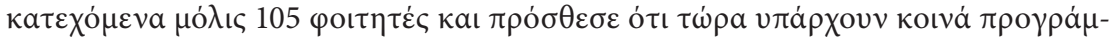

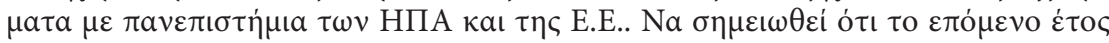

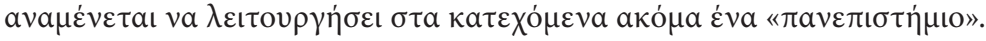




\section{Distinction for the "university" of Keryneia}

Paris-Sorbonne awards prize

The american "university" of Keryneia was listed among the top 1000 universities of the world in a special ceremony which took place at the Paris-Sorbonne university in France. [...] Initially, the "university" was listed among the top five Turkish universities. Following relevant recommendations, however, the "university" was registered as an academic institution of "north Cyprus."

Meanwhile, Nilgün Sarp, rector of the "university," stressed that "TRNC" has turned Cyprus into an island of education, saying that, at present, around 40000 students from various countries are enrolled in all six "universities" of the occupied areas. "Science knows no borders. It is universal. Although our country is not officially recognized, its universities are widely known" said Sarp, underlining that, today, the occupied areas host students from 57 countries. Explaining that the efforts by the pseudo-state encountered a lot of problems, Mr Sarp stressed that in 1979 only 105 students were studying in the occupied areas, and added that today there are joint projects with universities of the USA and the EU. It is worth noting that next year another "university" is expected to open in the occupied areas.

(Anonymous 19 November 2008: 6; translated and emphasized by the author $)^{10}$

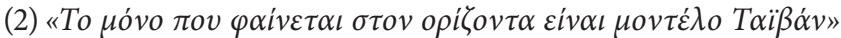

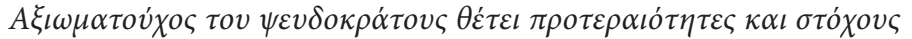

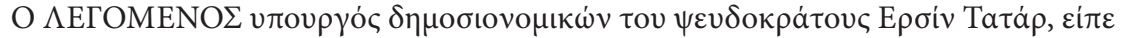

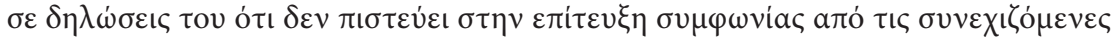

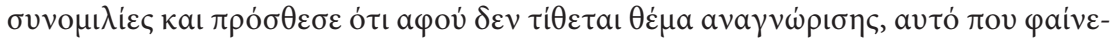

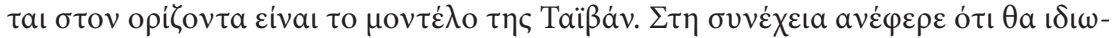

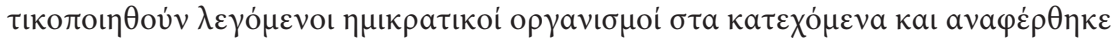

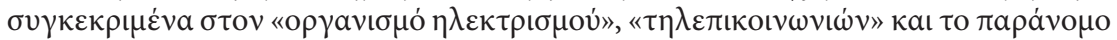

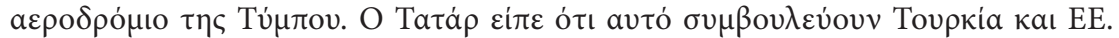

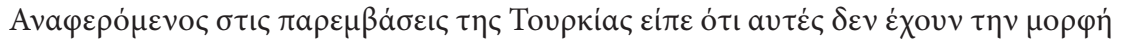

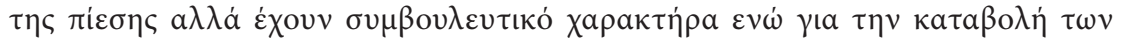

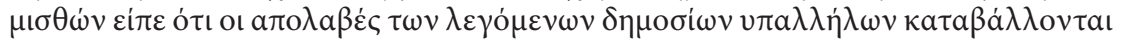

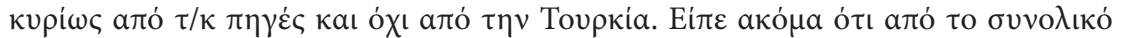

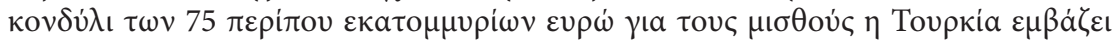

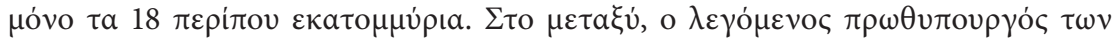

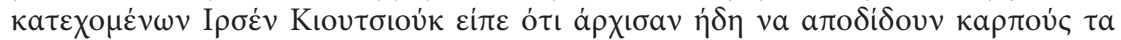

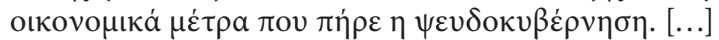

"The only option on the horizon is the Taiwan model"

Official of the pseudo-state sets priorities and aims

The so-called minister of finance of the pseudo-state, Ersin Tatar, stated that he does not believe an agreement will be reached through the ongoing talks and added that since the issue of recognition has not been posed, the only option on the horizon is the Taiwan model. He continued by mentioning that so-called semi-public institutions in the occupied areas will be privatized. He specifically mentioned the "electricity authority," the "telecommunications authority" and the illegal airport of Tymbou. Tatar said that this has been the advice given by Turkey and the EU. As to the interventions by Turkey, he said that these are not meant as pressure, but are of an advisory nature. As to the payment of salaries, he added that the salaries of the so-called civil servants are mainly paid by Turkish Cypriot resources and not by Turkey. He also said that of the total fund of 75 million Euros needed for salaries, Turkey only remits about 18 million. Meanwhile, the so-called prime minister of 
the occupied areas, İrsen Küçük, said that the financial measures taken by the pseudo-government have started paying off. [...]

(Anonymous 9 November 2010: 6; translated and emphasized by the author $)^{11}$

\section{(3) $Г K I O Y \Lambda$}

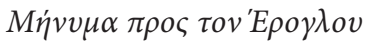

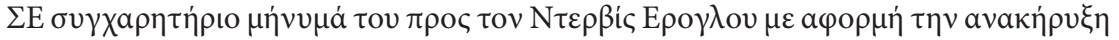

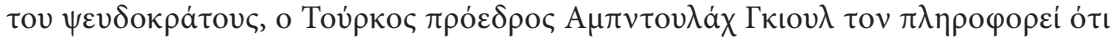

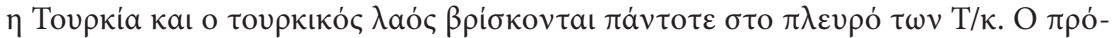

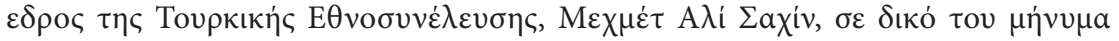

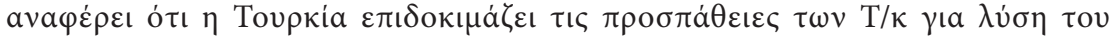

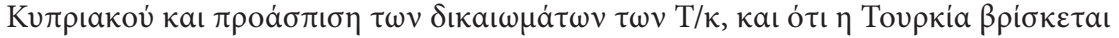

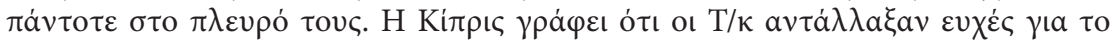

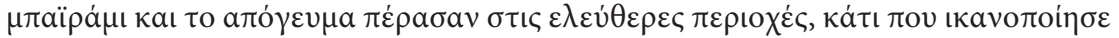

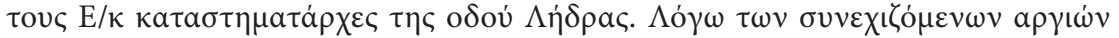

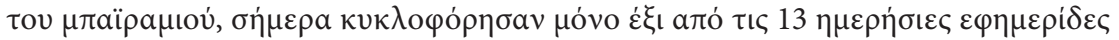

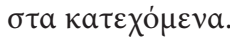

\section{Abdullah Gül}

Message to Eroğlu

In a congratulatory message to Derviş Eroğlu on the occasion of the declaration of independence of the pseudo-state, the Turkish President, Abdullah Gül, informs him that Turkey and the Turkish people are always by the Turkish Cypriots' side. The Speaker of the Grand National Assembly of Turkey, Mehmet Ali Şahin, stated in his message that Turkey approves of the efforts of the Turkish Cypriots towards a solution to the Cyprus issue and the protection of their rights, and that Turkey will always be by their side. The newspaper Kibris writes that the Turkish Cypriots exchanged Bayram wishes and that in the afternoon they crossed over to the free territories to the satisfaction of Greek Cypriot shop owners on Ledra street. Due to the continued Bayram holidays, only six out of 13 newspapers circulated today in the occupied areas.

(Anonymous 18 November 2010: 6; translated and emphasized by the author $)^{12}$

\subsubsection{Group B}

(4) 3.500 applications by foreign property buyers processed in one year

Turkish Cypriot daily Yeni Duzen (30.11.10) reports that Ilkay Kamil, self-styled minister of internal affairs of the breakaway regime, said that 3.500 applications by foreigners to buy property in the occupied areas of Cyprus were concluded during the past year.

Addressing the "assembly" yesterday, Kamil admitted that problems exist in the "land registry office" and added that the breakaway regime is exerting efforts to overcome the problem of lack of personnel. He also noted that automation is expected to be completed in 2011.

Kamil noted that the "ministry" preserves all the documents regarding those Turkish Cypriots who denounced their rights on their property in the free areas of Cyprus in return for property in the occupied part of the island from the breakaway regime. 
Kamil said the breakaway regime has no definite information regarding persons who sold their property in the government-controlled areas of the Republic, despite the fact that they renounced their rights on that property and in return were given property in the occupied areas of Cyprus. He said the regime is aware of rumours on this issue and if documented, the necessary "legal procedures" will follow.

Speaking at the same meeting of the "assembly," Turgay Avci, leader of the Freedom and Reform Party (ORP), referred to the same issue and recalled that, according to press reports, 500 Turkish Cypriot properties in the government-controlled areas of Cyprus have been sold. Avci criticized the "government" and the "state" for not taking on this issue.

Avci recalled that the law envisages five years imprisonment for those who sell their property in the free areas of Cyprus, despite the fact that they are given property of equivalent value in the occupied areas of the island in return of renouncing their rights on their property in the free areas of the Republic.

(Press \& Information Office 30 November 2010: 3; emphasized by the author) ${ }^{13}$

(5) 1. Erdogan demands legal action against protesters

Turkish Cypriot daily Kibris (07.02.11) reports that the Turkish Prime Minister Recep Tayyip Erdogan called the Turkish Cypriot leader Dervis Eroglu and asked him to bring to "justice" those who carried banners against Turkey during the "Communal Existence Rally" on 28 January.

Erdogan responded to press questions yesterday at Sabiha Gokcen International Airport before departing for Hatay. Asked to comment on the reaction caused in the occupied areas of Cyprus by his recent statements against the Turkish Cypriots (Tr. Note: See Turkish Cypriot and Turkish Media Review of 04.02.2011), and the protest to be held today on this issue, Erdogan said he discussed the issue with Eroglu. He added that this was the attitude of a group "connected with the south," as he described the government-controlled areas of the Republic of Cyprus.

[...] He said the necessary steps should be taken regarding these incidents. He noted that this is not the "way the TRNC people" approach the situation, adding that this is the behaviour of a "certain group which we know," a group "which gives the south the glad eye" and "wants to blow up the peace process."

Erdogan added: "I think that the TRNC administration will take the necessary stance against this group which wants to dynamite [the peace process]. We will also do what is necessary, our share. [...] 'If you know, do whatever is necessary,' we said. We, Turkey, cannot forgive such an attitude against Turkey, which until the period prior to 1974, had given its life, blood and everything for the TRNC."

(Press \& Information Office 05-07 February 2011; emphasized by the author $)^{14}$

In all the above examples, the interventionist practice of the text producers (be it journalists, translators, or other, see Fairclough 1992) ${ }^{15}$ is more than obvious. There is extensive use of quotation marks for referring to any kind of institution of the political formation in northern Cyprus, as well as extensive use of modifiers (see underlined instances), although there is a slight register difference between group A and group B examples. Some PIO examples (group B) reveal a stylistically more careful choice of modifiers (self-styled, government-controlled areas, breakaway regime) 
as opposed to some more intense choices in newspapers in examples 1-3 in group A (so-called, pseudo, occupied, etc.). Whatever the exact form of the intervention, what may remain uncontested is that the final product in all cases borders on the unfamiliar and the questionable, if not on the absurd. All of them raise a credibility issue; Turkish Cypriot and Turkish rectors or officials could never have made statements downgrading their own institutions. Nor would they have ever referred to "free" and "occupied" areas of the Republic of Cyprus. On the contrary, it is logical to assume that the originals must have been much more supportive of the independent status of the northern Cypriot political formation without labeling it in a negative way. The examples reveal that the narrative of the original has been replaced by its exact opposite - and it has been done so in a very visible way. What is less striking - but equally important - is that the only instances where the Turkish Cypriot entity and its institutions are not accompanied by any modifier is in statements which appear verbatim. So, in example A(1), in the only instance of a verbatim reproduction of what Rector Nilgün Sarp said, the word universities is not put in quotation marks. The same happens in example $\mathrm{B}(2)$, in the verbatim reproduction of Erdoğan's words from Turkish, where TRNC is again not accompanied by a modifier. This is obviously an ideologically marked use of reported speech here, with the direct and the indirect modes being deployed in a totally conflictual way.

Discussing the tasks that are assumed as part of the process of (news) translation, Bielsa and Bassnet note among others the task

of changing news angles and nuances, when the new informative context justifies it. [...] [T] he possibility of changing news angles in order to better fulfil the needs and expectations of a different audience pushes the very notion of equivalence to its limit, revealing how different versions of global news events can function in very diverse local contexts. The translator's visibility and transformative role in news production is directly related to this power to actually change the prevalent news angle or point of view from which events are narrated in order to produce a new text which can function more effectively as news for a different public. (Bielsa and Bassnett 2009: 93)

But what exactly does context justify and what exactly can be thought of as functioning more effectively in the above examples? And what exactly licenses the indirect mode of reported speech to display significant differences from the direct mode? The next section will discuss these issues from the ethical point of view in more detail, as the above examples of news translation from the Cypriot context cannot be dismissed simply on the grounds that they are blunt distortions.

\section{The Cypriot context: A case of ethical hybridity or ethical violation?}

News reporting, although thought of as striving for objectivity, always involves commentary, stance and ideological manipulation, whether it is original text or text constructed through translation. This has been widely documented in bibliography on news texts and news translation (see, for example, Fowler 1991; Fairclough 1995; Kelly 1998; Bassnett 2004; Holland 2006; Valdeón 2007). Thus, reporting is less amenable to ethical restrictions than translation in the conventional sense, which by definition implies voicing the Other. The problems arise when the two come together and translational norms may clash with the norms governing news production. At the surface level, the clash is quickly resolved, as the norms of the news industry are 
overwhelming. ${ }^{16}$ It is precisely in such cases that translators become what Valdeón has termed intermediaries:

[I]ntermediaries might use the information to instil the text with views that are alien to the discourse of the original but stem from the corporation or from personal convictions and beliefs. That is, the writers might have the interests or ideological position of the corporation in mind, or they might have recourse to their own perception of the world to alter the content, to make readjustments that better suit their own interpretation of the event. (Valdeón 2007: 241)

The same may happen with other forms of translation as well, perhaps to varying degrees. Venuti $(1995 ; 1998)$ has repeatedly asserted the impossibility of representing the Other in an unmediated way. It is always the type and power of norms which will determine how tolerant each genre may be towards ideological manipulation. In previous work, we described this varying tolerance as ethical relativity, which could be defined as "the fluctuation of ethical thresholds impinging on translation through inherently subjective values and narratives that govern translation behavior by creating equally subjective norms" (Floros 2011: 71). In consequence, the above mentioned injunction of voicing the Other, which is assumed to be generally valid for translation, is attenuated or reinforced by the narratives and norms which happen to be dominant in each case. Undoubtedly, news translation presents a case where ethical thresholds are pushed to relatively low limits because of the subjectivity of the norms governing the dominant part of the profession (journalistic norms).

To recall the specific blend characterizing news translation (translation and additional reshaping) and to return to the Cypriot context, the following needs to be noted: the text producers follow norms created on the basis of an overwhelming national ideology and of their own perceptions of how to satisfy public feeling and disseminate national ideology. In so doing, they extend their sphere of influence almost blindly. The norms they follow remain very powerful, partly because they stem from a perception of the dominant ideology as national cause - and not surprisingly so, given the dramatic and painful circumstances for all sides involved. Although not documented in any handbook or draft guidelines, these norms have acquired their power in a covert way, mainly through oral dissemination. However, the problems arise not because of a shifting of angle, which is more or less understandable and explicable in terms of political attitude, but because of the expansion of the shift in the semantic level in a highly visible way. ${ }^{17}$ As a result, this shift has repercussions on the very informativity and credibility of the product and cannot be considered acceptable: the way journalistic norms and practices dominate translation in the Cypriot context exceeds the lower limits of ethical relativity and borders on ethical violation in all cases presented above. Furthermore, it would be interesting to see the consequences this violation has on the audience. In Floros 2009 and 2011, it was shown through the examination of classroom discussions that satisfying public feeling and complying with the urge to defend the national cause may actually harm the intended audience by almost seducing it: what could be the political gain from cultivating in Cypriot readers the illusion of non-Cypriots complying with the way Cypriot demands are articulated? Even if we adopt the Marxist stance towards news production (according to which news is a marketable product), another interesting question arises in the case of group B examples, intended also for the international media: How successful is the selling of news to other agencies when intervention is 
so blatantly visible? This is another interesting question worth examining, but it goes beyond the scope of the present work.

Perhaps it is time to allow the notion of faithfulness - if only to the text - to regain some ground at the expense of the (always questionable) attempt to restore objectivity. A more faithful rendering of the statements in the above examples would serve as a moment of goading the audience towards a more self-reflexive stance. More importantly, translators would thus rediscover the political role of translation as a vehicle for dealing with discord instead of perpetuating it. A possible way for this to happen might be to turn ethical violation into ethical hybridity in news translation. This would entail the recognition of translation as a particular kind of activity following its own ethics within news production. Even if a reshaping and repurposing is ultimately necessary, it would be useful to take the translational norms into consideration alongside journalistic norms. Such a return to a synergy would entail treating reported speech, for example, as an instance where particular attention needs to be paid, as reported speech is the structure most widely used in news.

But, again, reported speech is not unproblematic in terms of ethics. Normally, reported speech is widely used in news production in order to ensure objectivity and "assure readers that different perspectives are being taken into account" (Belmonte, McCabe et al. 2010: 228). Such objectivity is, however, not achieved, especially when indirect speech (including free indirect speech) is used (see, among others, Waugh 1995; Redeker 1996; Belmonte, McCabe et al. 2010). As for direct speech, there are voices supporting the anti-faithfulness argument (see Tannen 1989; Fludernik 1993) and voices in favor of it (see Short, Semino et al. 2002). The fact remains that, especially in the case of news reporting, almost all modes of quoting (direct speech, indirect speech, etc.) are perceived as allowing for some ideological intervention (see Obiedat 2006; Smirnova 2009), and what allows reported speech to function as a mediated representation rather than a faithful reproduction is not only the presence of two different voices, but also the specific layering of speech events. Drawing on Vološinov (1973) and Pierce (1955), Waugh (1995: 135) distinguishes among three speech events in a news text containing reported speech: the reporting (the journalistic text), the reported (represented in the text) and the original, real-world event. The reported speech instance is thus indexical of an event outside the quoting text. The situation gets even more complicated when reported speech appears as a translated instance. In all the examples presented here, the original speech event was uttered in Turkish, while the reporting and the reported speech events were uttered either in Greek (examples A(1), A(2), A(3)) or in English (examples B(4), B(5)). Thus, it is not only the indexicality inherent in reported speech which may account for the mediated representation of the original speech event, but also the process of translation, which implies mediation by necessity.

As a result, although text producers usually try to corroborate their claims by making use of the (relative) authenticity of reported speech, our examples from the Cypriot context show that text producers try to corroborate their claims by explicitly manipulating this sensitive authenticity, which is seen as yet another chance to disseminate national ideology. In addition, the dominance of the reporting voice in indirect speech and the possibility of blurring the borders between the journalist's commentary and indirect speech when the latter is used (Waugh 1995: 146) may sufficiently explain why intervention appears exclusively in indirect speech 
instances, while direct speech instances are left unaffected. Nevertheless, the fact that reported speech - particularly the indirect mode - offers itself to an easily exploitable ambiguity does not alleviate responsibility on the part of text producers. On the contrary, text producers should by definition be more sensitive to the complexities described here. A higher ethical awareness in this regard is what might bring about a clearer differentiation between instances where intervention is less tolerable and instances where the producer's stance can be articulated. A reconsideration of the norms allowing for extreme intervention will, ultimately, create a space for ethical hybridity.

\section{Conclusion}

The practices detected in the examples discussed reveal that, in terms of ethics, translation is not treated as translation when it forms part of a larger textual product. However, this paper calls for a reconsideration of such practices. It seems useful for journalists, translators and the media to be conscious of the existence of ethical thresholds in translation, especially when credibility and responsibility are at stake. The investigation of the Cypriot context could show that manipulative norms should not always gain primacy over basic translational norms. Such primacy could lead to an ethical violation, which is of no benefit to any of the parties involved, either to the assumed audience or to the medium itself. Nevertheless, the ethically-driven respect for the source material advocated for in this paper is an ideal situation, which is unfortunately the exact opposite of a number of real situations worldwide.

\section{ACKNOWLEDGMENTS}

I would like to thank the participants of the Istanbul conference (2009), where an early version of this work was presented, for the invaluable feedback.

\section{NOTES}

1. Press and Information Office, Ministry of Interior, Republic of Cyprus. Visited on 10 June 2011, $<$ http://www.moi.gov.cy/moi/pio/pio.nsf/about_us_en/about_us_en?OpenDocument $>$.

2. On intertextuality in translation see, for example, Hatim (1997) and also Lawrence Venuti's lecture: Venuti, Lawrence (11 May 2011): Translation, Intertextuality, Interpretation. Unpublished lecture. Aristotle University of Thessaloniki. (Pre-conference event of the 3rd Meeting on Greek-speaking Translation Studies, 12-14 May 2011, Thessaloniki).

3. What is meant here by integration is a particular complementarity and interdependence of norms and practices, with the other profession maintaining a sort of primacy.

4. For the understanding of narrative followed here, see Baker (2006).

5. Cyprus Ministry of Foreign Affairs (May 2006): Historical Review. Visited on 10 June 2011, <http:// www.mfa.gov.cy/mfa/mfa2006.nsf/cyprus01_en/cyprus01_en?OpenDocument>.

6. Interestingly, not only the state TV channels and radio stations (CyBC) follow this policy widely, but also individual newspaper publishers and private TV channels. However, this acceptance should be understood merely as the dominant trend, as there is yet no exhaustive investigation of all forms of news transmission, e.g., СуBC news in Turkish.

7. Although not an official language in Cyprus, English enjoys a special status and is used widely (see Tsiplakou 2009).

8. Politis Newspaper Archives. Visited on 10 June 2011, <http://www.politis-news.com>.

9. Fileleftheros Newspaper Archives. Visited on 10 June 2011, <http://www.philenews.com>.

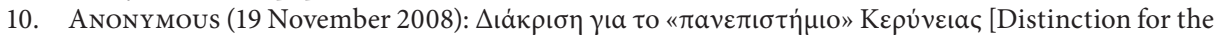
"university" of Keryneia]. Politis 10(3468):6. Visited on 10 June 2011, <http://www.politis-news.com>. 


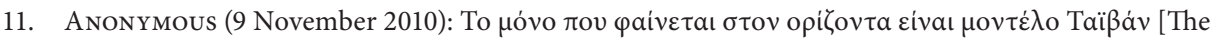
only option on the horizon is the Taiwan model]. Fileleftheros 55(18338):6. Visited on 10 June 2011, $<$ http://www.philenews.com>.

12. AnOnymous (18 November 2010): TKIOY $\Lambda$ [Abdullah Gül]. Fileleftheros 55(18347):6. Visited on 10 June 2011, <http://www.philenews.com>.

13. Press \& Information Office (30 November 2010): Turkish Cypriot and Turkish Media Review. No 228/10, 11p. Visited on 10 June 2011,

<https://docs.google.com/viewer?url=http\%3A\%2F\%2Fwww.moi.gov.cy\%2Fmoi\%2Fpio\%2Fpio. nsf\%2FAll\%2F2652E138817CAB4DC22577EB0042AC5F\%2F\%24file\%2F301110.doc>.

14. Press \& Information Office (05-07 February 2011): Turkish Cypriot and Turkish Media Review. No 25/11. Visited on 10 June 2011,

<http://www.moi.gov.cy/moi/PIO/PIO.nsf/d2f0876e1500506ac2257076004d01cb/dd834822f8e326 17c22578300044c88e?OpenDocument\&print>.

15. The use of the term text producers implies that no information could be retrieved as to any specific translator (or journalist) or as to the exact source of the quoted material.

16. In relation to this, Robinson (1991) spoke about external ethics such as the significant thirds and the social context of a translation situation.

17. See also Conway (2008) on what he refers to as essentially contested concepts. In our case, essentially contested concepts would not be notions such as 'war' and 'terror,' but concepts of institutional nature.

\section{REFERENCES}

BAKer, Mona (2006): Translation and Conflict: A Narrative Account. London: Routledge.

Barthes, Roland (1981): Theory of the text. In: Robert Young, ed. Untying the Text. Boston: Routledge \& Kegan Paul, 31-47.

Bassnett, Susan (2004): Trusting reporters: What did Saddam say? The Linguist. 43(6):176-178.

Bassnett, Susan (2006): Introduction. In: Kyle Conway and Susan BassnetT, eds. Translation in Global News. Proceedings of the conference held at the University of Warwick, 23 June 2006. Coventry: University of Warwick, 5-7.

BeLL, Allan (1991): The Language of News Media. Oxford: Blackwell.

Belmonte, Isabel A., McCabe, Anne and Chornet-Roses, Daniel (2010): In their own words: The construction of the image of the immigrant in peninsular Spanish broadsheets and freesheets. Discourse \& Communication. 4(3):227-242.

BielsA, Esperança (2007): Translation in global news agencies. Target. 19(1):135-155.

Bielsa, Esperança and Bassnett, Susan (2009): Translation in Global News. London: Routledge.

Conway, Kyle (2006): A cultural studies approach to translation in the news: The case of Canada and Quebec. In: Kyle Conway and Susan BAssnetr, eds. Translation in Global News. Proceedings of the conference held at the University of Warwick, 23 June 2006. Coventry: University of Warwick, 47-57.

Conway, Kyle (2008): A cultural studies approach to semantic instability: The case of news translation. Linguistica Antverpiensia New Series. 7(2008):29-43.

ERDAL, Ivar J. (2009): Repurposing of content in multi-platform news production. Journalism Practice. 3(2):178-195.

Fairclough, Norman (1992): Discourse and Social Change. London: Polity Press.

Fairclough, Norman (1995): Media Discourse. London: Arnold.

Floros, Georgios (2009): News translation in Cyprus: Between report and national policy. In: Hasan Anamur, Alev Bulut and Arsun Uras-Yilmaz, eds. Translation in All Its Aspects with Focus on International Dialogue. (Proceedings of the International Colloquium of Translation, 21-23 October 2009). Istanbul: Çeviri Derneği, 82-86.

Floros, Georgios (2011): 'Ethics-less' theories and 'ethical' practices: On ethical relativity in translation. The Interpreter and Translator Trainer. 5(1):65-92.

Fludernik, Monika (1993): The Fictions of Language and the Languages of Fiction. London: Routledge. 
Fowler, Roger (1991): Language in the News, Discourse and Ideology in the Press. London: Routledge.

FujII, Akio (1988): News translation in Japan. Meta. 33(1):32-37.

Gambier, Yves (2006): Transformations in international news. In: Kyle Conway and Susan Bassnett, eds. Translation in Global News. Proceedings of the conference held at the University of Warwick, 23 June 2006. Coventry: University of Warwick, 9-21.

HAтім, Basil (1997): Intertextual intrusions: Towards a framework for harnessing the power of the absent text in translation. In: Karl Simms, ed. Translating Sensitive Texts: Linguistic Aspects. Amsterdam: Rodopi, 29-45.

Holland, Robert (2006): Language(s) in the global news: Translation, audience design and discourse (mis)interpretation. Target. 18(2):229-259.

HuRsti, Kristian (2001): An insider's view on transformation and transfer in international news communication. Helsinki English Studies. 1(2001):1-11 Visited 10 June 2011, <http://www. eng.helsinki.fi/hes/Translation/insiders_viewl.htm>.

KANG, Ji-Hae (2007): Recontextualization of news discourse: A case study of translation of news discourse on North Korea. The Translator. 13(2):219-242.

Kelly, Dorothy (1998): Ideological implications of translation decisions: Positive self- and negative other presentation. Quaderns. 1(1998):57-63.

Kristeva, Julia (1984): Revolution in Poetic Language. (Translated by Margaret Waller) New York: Columbia University Press.

Nord, Christiane (2005): Training functional translators. In: Martha Tennent, ed. Training for the New Millennium: Pedagogies for Translation and Interpreting. Amsterdam: John Benjamins, 209-223.

ОвіеDAт, Nawaf (2006): The pragma-ideological implications of using reported speech: The case of reporting on the Al-Aqsa Intifada. Pragmatics. 16(2/3):275-304.

Orengo, Alberto (2005): Localizing news: Translation and the 'global-national' dichotomy. Language and Intercultural Communication. 5(2):168-187.

Pierce, Charles S. (1955): Logic as semiotics: The theory of signs. In: Justus Buchler, ed. Philosophical Writings. New York: Dover, 98-119.

REDEKER, Gisela (1996): Free indirect discourse in newspaper reports. In: Crit Cremers and Marcel den Dikken, eds. Linguistics in the Netherlands. Amsterdam: John Benjamins, 221-232.

Robinson, Douglas (1991): The Translator's Turn. Baltimore/London: Johns Hopkins University Press.

Short, Mick, Semino, Elena and Wynne, Martin (2002): Revisiting the notion of faithfulness in discourse report/(re)presentation using a corpus approach. Language and Literature. 11(4):325-355.

Simon, Sherry (1996): Gender in Translation: Cultural Identity and the Politics of Transmission. London/New York: Routledge.

Simon, Sherry and St-Pierre, Paul, eds. (2000): Changing the Terms: Translating in the Postcolonial Era. Ottawa: Ottawa University Press.

Smirnova, Alla V. (2009): Reported speech as an element of argumentative newspaper discourse. Discourse \& Communication. 3(1):79-103.

Sorby, Stella (2006): Translating news from English to Chinese: Complimentary and derogatory language usage. In: Kyle Conway and Susan Bassnett, eds. Translation in Global News. Proceedings of the conference held at the University of Warwick, 23 June 2006. Coventry: University of Warwick, 113-126.

Stetting, Karen (1989): Transediting - A new term for coping with the grey area between editing and translating. In: Graham Caie, Kirsten HaAstrup and Arnt Jakobsen, eds. Proceedings from the Fourth Nordic Conference for English Studies. Copenhagen: Department of English, University of Copenhagen, 371-382.

Tannen, Deborah (1989): Talking Voices: Repetition, Dialogue and Imagery in Conversational Discourse. Cambridge: Cambridge University Press. 
TsAI, Claire (2005): Inside the television newsroom: An insider's view of international news translation in Taiwan. Language and Intercultural Communication. 5(2):145-153.

Tsıplakou, Stavroula (2009): English in Cyprus: Outer or expanding circle? Anglistik - International Journal of English Studies. 20(2):75-88.

Tymoczko, Maria and Gentzler, Edwin, eds. (2002): Translation and Power. Amherst/Boston: University of Massachusetts Press.

VAldeón, Roberto (2005): The CNN en Español news. Perspectives. 13(4):255-267.

VALDEÓn, Roberto (2007): Political and sexist bias in news translation. TRANS. 11(2007):231-243.

Venuti, Lawrence (1995): The Translator's Invisibility. London/New York: Routledge.

Venuti, Lawrence (1998): The Scandals of Translation. London: Routledge.

Vološinov, Valentin N. (1973): Marxism and the Philosophy of Language. Cambridge: Harvard University Press.

VuORInen, Erkka (1995). News translation as gatekeeping. In: Mary Snell-Hornby, Zuzana Jettmarová and Klaus KaInde, eds. Translation as Intercultural Communication. Amsterdam/Philadelphia: John Benjamins, 161-172.

WAUGH, Linda R. (1995): Reported speech in journalistic discourse: The relation of function and text. Text. 15(1):129-173.

White, David M. (1950): The 'gatekeeper': A case study in the selection of news. Journalism Quarterly. 27:383-390. 